\title{
The economic resilience of Irish counties for subsequent recessions and the impact of population distribution on resilience
}

\author{
B. Hennebry (i) \\ Athlone Institute of Technology, Athlone, Ireland; bhennebry@ait.ie
}

\begin{abstract}
Relevance. Much research was undertaken on regional economic resilience after the financial crisis of 2008. The current crisis caused by Covid19 provides an opportunity to understand further the nature of regional economic resilience. It also provides an opportunity to analyse the urban-rural divide of economic resilience for two recessions. Research objective. There are two main objectives of this study Firstly, to understand if resilience to one recession provides a good indication of resilience to a subsequent recession. The second aim is to understand the urban-rural differences in regional economic resilience in Ireland. Data and methods. This is a quantitative study which uses data from the Irish Central Statistics Office regarding unemployment and population distribution. To understand economic resilience a sensitivity index is used and to check for correlation the Pearson coefficient is used. Results. Results show that there is no correlation between resilience to the financial crisis and resilience to the Covid19 crisis. Population distribution was not a determinant of resilience to the financial crisis. However, population distribution was a determinant of resilience to the Covid19 crisis. Counties with high population in 'independent urban towns' or 'rural areas with moderate urban influence' were more resilient while counties with high population in 'satellite urban towns' or 'rural areas with high urban influence' were more vulnerable. Conclusions. Economic resilience to one recession is not a good indication of resilience to future recessions. Counties with population in urban centres or more reliant on urban areas were less resilient to the Covid19 crisis.
\end{abstract}

\section{KEYWORDS}

regional economic resilience; urban-rural divide; Ireland; Covid19; recession

\section{ACKNOWLEDGEMENTS}

This research has received funding from the European Union's Horizon 2020 research and innovation program under the Marie Skłodowska Curie grant agreement number 721999.

\section{FOR CITATION}

Hennebry, B. (2020) The economic resilience of Irish counties for subsequent recessions and the impact of population distribution on resilience. R-economy, 6(3), 146-153. doi: $10.15826 /$ recon.2020.6.3.012

\section{Экономическая устойчивость ирландских городов к дальнейшим спадам и роль распределения городского и сельского населения}

\section{Б. Хеннебри (iD \\ Технологический институт Атлон, Атлон, Ирландия; bhennebry@ait.ie}

\section{КЛЮЧЕВЫЕ СЛОВА}

региональная экономическая устойчивость; разрыв между городом и деревней; Ирландия; COVID-19; рецессия

\section{БЛАГОДАРНОСТИ}

Это исследование получило финансирование в рамках исследовательской и инновационной программы Европейского Союза Horizon 2020 в рамках грантового соглашения Марии Склодовской Кюри № 721999. 
селения было определяющим фактором устойчивости к кризису Covid19. Округа с высокой численностью населения в «независимых городских городах» или "сельских районах с умеренным городским влиянием» были более устойчивыми, тогда как графства с высокой численностью населения в «городах-спутниках» или «сельских районах с сильным городским влиянием» были более уязвимыми. Выводы. Устойчивость экономики к одной рецессии - не лучший показатель устойчивости к будущим рецессиям. Округа с населением в городских центрах или более зависимыми от городских районов оказались менее устойчивыми к кризису Covid19.

\section{ДЛЯ ЦИТИРОВАНИЯ}

Hennebry, B. (2020) The economic resilience of Irish counties for subsequent recessions and the impact of population distribution on resilience. R-economy, 6(3), 146-153. doi: $10.15826 /$ recon.2020.6.3.012

\section{Introduction}

Resilience became a very popular topic in regional economics following the financial crisis of 2008 (Hassink, 2010; Fröhlich \& Hassink, 2018). Much research was carried out regarding the theoretical underpinnings of resilience (Simmie \& Martin, 2010; Lang, 2012; Martin, 2012; Tóth, 2015) and empirical research was done to understand the determinants of resilience. One shortcoming of this research was that it focused on a single recession and it is unclear if the determinants of resilience in face of the financial crisis would also be factors in determining resilience for any future recession. The contraction of the economy from Covid19 now provides us with an opportunity to understand if regions which were resilient in light of the financial crisis are also resilient in terms of the Covid19 crisis.

There is some indication that urban centres and more accessible regions were more resilient to the financial crisis (ESPON, 2014; Lapuh, 2018) and that there was an urban-rural divide in terms of the recovery (Hennebry, 2018). It will be interesting to see if there is an urban-rural divide in relation to the Covid19 crisis also. Thus, this paper has two research questions:

1) Were Irish counties that were resilient during the financial crisis of 2008 also resilient during the Covid19 crisis?

2) Is there an urban-rural divide in terms of regional economic resilience for Irish counties?

This paper focuses on Ireland as it provides an interesting case study. Ireland was one of the European countries worst affected by the financial crisis. It was labelled as one of the 'PIIGS' countries (Portugal, Italy, Ireland, Greece and Spain), an acronym used for the countries that suffered the worst recessions in Europe. However, Ireland did recover strongly from the financial crisis (Hennebry, 2018). Ireland's recovery from the financial crisis has been studied (Fitzgerald, 2014; Ruane, 2016), especially the regional aspect of the recovery (Morgenroth,
2014; Breathnach et al., 2015). Ireland has also been affected by rising unemployment due to the Covid19 crisis, the number of people on the live register or claiming the pandemic unemployment payment (PUP) increased by more than three times between February and April 2020 (Central Statistics Office).

The Irish government has responded by introducing some new income support measures. The government introduced a wage subsidy scheme, which will subsidise up to $70 \%$ of employee income (capped at $€ 410$ a week) for all firms in sectors that have seen a $25 \%$ fall in revenue. They have also introduced the PUP of $€ 350$ a week for employees or self-employed people who have lost their jobs due to the Covid19 crisis (Central Bank of Ireland, 2020).

\section{Theoretical Basis}

The theoretical background for studying resilience in terms of regional economics is relatively new and therefor regional economists tend to borrow the definition of 'resilience' from other fields of study (Martin \& Sunley, 2015). These can be divided into three broad groups and are summarised in table 1 . The first definition comes from engineering and considers resilience to be the speed at which an economy returns to equilibrium (Holling, 1996), this is generally accepted by the neoclassical school of thought in economics as it sees an economy as only having a single equilibrium point. The second definition comes from ecological science and defines resilience as an economy's ability to absorb shocks before altering its structure (Holling, 1973). This sees an economy as having several equilibrium points and is therefore seen as complying with the Keynesian school of thought (Davoudi, 2012). The third definition comes from psychological sciences and organisational theory and sees resilience as an economy's ability to adapt in anticipation of, or response to, shocks. This definition suits an evolutionary economics approach 
as it considers the possibility of many equilibrium points and these points change over time (Berkes \& Folke, 1998).

Table 1

\begin{tabular}{|l|l|l|l|}
\hline \multicolumn{5}{|c|}{ Definitions of Resilience } \\
\hline Field of Study & \multicolumn{1}{|c|}{ Definition } & $\begin{array}{l}\text { Equilibrium } \\
\text { Points }\end{array}$ & $\begin{array}{l}\text { School of } \\
\text { Thought }\end{array}$ \\
\hline Engineering & $\begin{array}{l}\text { Speed of return } \\
\text { to equilibrium }\end{array}$ & $\begin{array}{l}\text { Only one } \\
\text { equilibrium } \\
\text { point }\end{array}$ & $\begin{array}{l}\text { Neoclas- } \\
\text { sical }\end{array}$ \\
\hline $\begin{array}{l}\text { Ecological } \\
\text { science }\end{array}$ & $\begin{array}{l}\text { Ability to absorb } \\
\text { shocks before } \\
\text { altering its } \\
\text { structure }\end{array}$ & $\begin{array}{l}\text { Several } \\
\text { equilibrium } \\
\text { points }\end{array}$ & Keynesian \\
\hline $\begin{array}{l}\text { Psychological } \\
\text { sciences and } \\
\text { organisational } \\
\text { theory }\end{array}$ & $\begin{array}{l}\text { Ability to adapt } \\
\text { in anticipation } \\
\text { of, or response } \\
\text { to, shocks }\end{array}$ & $\begin{array}{l}\text { Equilibrium } \\
\text { points change } \\
\text { over time }\end{array}$ & $\begin{array}{l}\text { Evolutio- } \\
\text { nary Eco- } \\
\text { nomics }\end{array}$ \\
\hline
\end{tabular}

Source: Authors own work

The most accepted definition of resilience in regional economics comes from Martin and Sunley $(2015$, p. 13$)$ and attempts to blend the three above definitions. They define resilience as:

"the capacity of a regional or local economy to withstand or recover from market, competitive and environmental shocks to its developmental growth path, if necessary by undergoing adaptive changes to its economic structures and its social and institutional arrangements, so as to maintain or restore its previous developmental path, or transit to a new sustainable path characterized by a fuller and more productive use of its physical, human and environmental resources."

There have been many empirical studies on the determinants of regional economic resilience. Dokic et al. (2016), focusing on Croatia, found that the recession led to increasing regional disparities and that construction and trade were the most important determinants of resilience. For regions in Italy, cultural behaviours have been shown to contribute to regional resilience (Cellini and Cuccia, 2019). Lapuh (2018) found that for municipalities in Slovenia important determinants of resilience included regions being export orientated, densely populated, and having a well-educated work force.

There have been a number of studies done focusing specifically on resilience of cities and urban regions (Simmie, 2017; Tan \& et al., 2017; Martin \& Gardiner, 2019) but much less research has been done focusing specifically on rural regions. Sánchez-Zamora et al. (2014) focus specifically on rural regions in the Andalusia region of Spain and find that economic diversification is important for building resilience. They also found that employment in agriculture is good for resilience as it acts as a 'haven sector' during recessions. Hennebry (2020) analyses the determinants of economic resilience for rural regions in Portugal and also finds that agriculture has a positive impact on resilience.

This paper will add to the literature of regional resilience by examining the correlation between resilience to the financial crisis and resilience to the Covid19 crisis for counties in Ireland. It will also analyse how population distribution of Irish counties impacts regional resilience.

\section{Methods and Data}

This study focuses on Ireland, which consists of 26 counties (i.e. the six counties of Northern Ireland are not included). The data in this study comes from Ireland's Central Statistics Office ${ }^{1}$. When referring to unemployment it is in reference to the number of people on the 'Live Register' and people in receipt of the PUP. The 'Live Register' refers to people that are registered for unemployment assistance. The PUP is an additional payment introduced to help people who lost their jobs due to the Covid19 crisis.

The data for 'Population Distribution' comes from the 2016 census, also available from the central statistics office. It divides the residence of the population into six categories: cities, satellite urban towns, independent urban towns, rural areas with high urban influence, rural areas with moderate urban influence and highly rural/remote areas. A table showing the percentage of people residing in each category for all counties is provided in the appendix.

There are numerous ways to measure regional economic resilience (Ringwood et al., 2018). The method used for this paper will be similar to the employment sensitivity index proposed by Martin (2012):

$$
\beta=\frac{\Delta U n C / U n C}{\Delta U n N / U n N},
$$

where $U n C$ is unemployment in the county, and $U n N$ is unemployment in the nation. This formula compares the change in number of people unemployed in a county to the change in the number of people unemployed in the whole nation. A result of greater than 1 would indicate that a region is

${ }^{1}$ Available from https://www.cso.ie/en/databases/ 
more vulnerable to changes in the national economy, i.e. the number of unemployed increased more than proportionately in the county compared to the nation. While a score of less than 1 would signify that a region is relatively resilient, that is to say, the number of people unemployed in the county increased by a smaller proportion than the nation's unemployment as a whole. In contrast to Martin (2012), who used a single time period for the peak and trough for all regions, this paper uses a method similar to Sensier and Artis (2014). In their work, Sensier and Artis (2014) used a more flexible method that allows for different start points and end points for the recession in each region. We consider the start point of the recession to be the month with the lowest unemployment and the end point of the recession is considered to be the month with the highest unemployment.

To check for correlation, we use the Pearson correlation method. This is a bivariate method and "was the first formal correlation measure, and it is still the most widely used measure of relationship" (Rodgers \& Nicewander, 1988, p. 61). It is suitable for quantitative variables and is a "measure of the strength of the linear relationship between two such variables" (Hauke \& Kossowski, 2011, p. 88).

\section{Results}

The first goal of this research was to understand if there was a correlation between economic resilience to the Covid19 crisis and economic resilience to the financial crisis. For that reason, the sensitivity index described above was calculated for all 26 counties in Ireland in response to both recessions. The results are presented in table 2 .

The Pearson correlation method was used to check if there was a correlation between economic resilience to the Covid19 crisis and economic resilience to the financial crisis. We can see examples above of counties that were resilient to both (e.g. Waterford) and counties that were vulnerable to both (e.g. Meath), however the Pearson coefficient is 0.29 with a P-value of 0.15 . This means that the result is statistically insignificant i.e. counties which were resilient to the financial crisis were not necessarily resilient to the Covid19 crisis.

The geographic distribution of the sensitivity index in relation to the Covid19 crisis is presented in figure 1. It is hard to see any clear geograph- ic pattern in the resilience to the Covid19 crisis. This is in contrast to the geographic distribution of the sensitivity index in relation to the financial crisis (shown in figure 2). For the financial crisis the vulnerable counties were those that were close in proximity to Dublin, even though Dublin itself was not vulnerable. The resilient counties were those on the west of the country. One interesting comparison is the lack of strong resilience for counties during the financial crisis compared with the Covid19 crisis. For the financial crisis no county showed strong resilience (a sensitivity score of less than 0.75). However, there are eight counties that have shown strong resilience to the Covid19 crisis.

Table 2

Sensitivity Index in relation to Covid 19 crisis and financial crisis

\begin{tabular}{|c|c|c|}
\hline & $\begin{array}{c}\text { Resilience to Covid19 } \\
\text { crisis }\end{array}$ & $\begin{array}{c}\text { Resilience } \\
\text { to Financial Crisis }\end{array}$ \\
\hline Carlow & 0.7158 & 1.3794 \\
\hline Cavan & 0.9424 & 1.2296 \\
\hline Clare & 0.9492 & 0.9011 \\
\hline Cork & 1.2563 & 1.0541 \\
\hline Donegal & 0.7382 & 0.8531 \\
\hline Dublin & 1.1671 & 0.9348 \\
\hline Galway & 1.0257 & 0.9266 \\
\hline Kerry & 0.8980 & 0.9679 \\
\hline Kildare & 1.0436 & 1.3652 \\
\hline Kilkenny & 1.0772 & 1.0436 \\
\hline Laois & 0.7114 & 1.7857 \\
\hline Leitrim & 0.7676 & 1.1852 \\
\hline Limerick & 0.9885 & 1.1074 \\
\hline Longford & 0.5811 & 0.9058 \\
\hline Louth & 0.7130 & 0.9183 \\
\hline Mayo & 0.7848 & 0.9907 \\
\hline Meath & 1.7714 & 1.5363 \\
\hline Monaghan & 1.0363 & 1.2883 \\
\hline Offaly & 0.7273 & 1.2126 \\
\hline Roscommon & 1.0418 & 1.2092 \\
\hline Sligo & 0.8909 & 1.1013 \\
\hline Tipperary & 0.7782 & 1.2212 \\
\hline Waterford & 0.6167 & 0.7611 \\
\hline Westmeath & 0.7809 & 0.9479 \\
\hline Wexford & 0.6874 & 1.0196 \\
\hline Wicklow & 1.0529 & 1.0988 \\
\hline
\end{tabular}

Source: Own calculations based on data from central statistics office. 


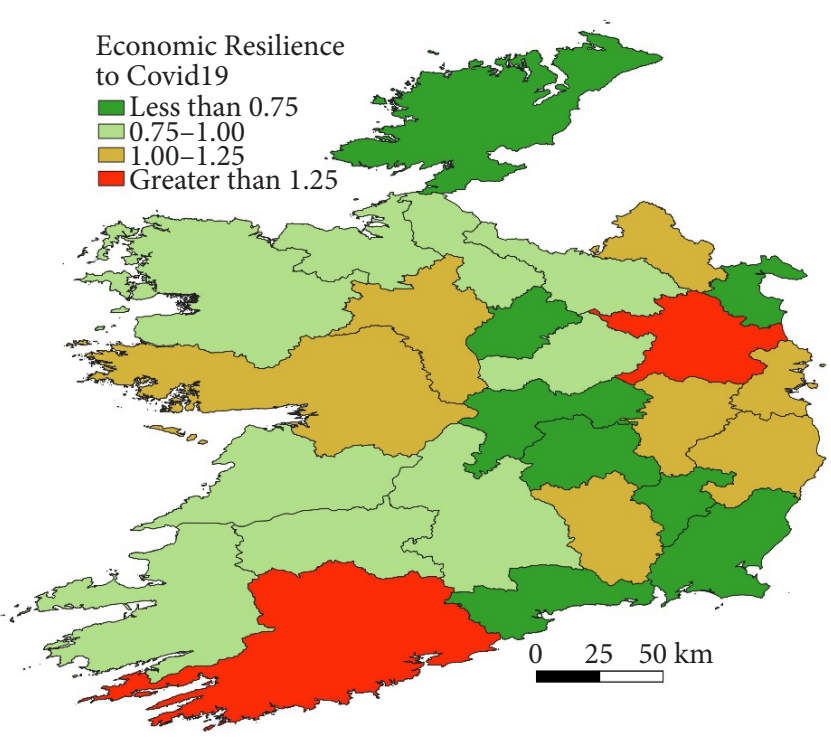

Figure 1. Economic resilience to Covid19 crisis Source: Own calculations based on data from central statistics office

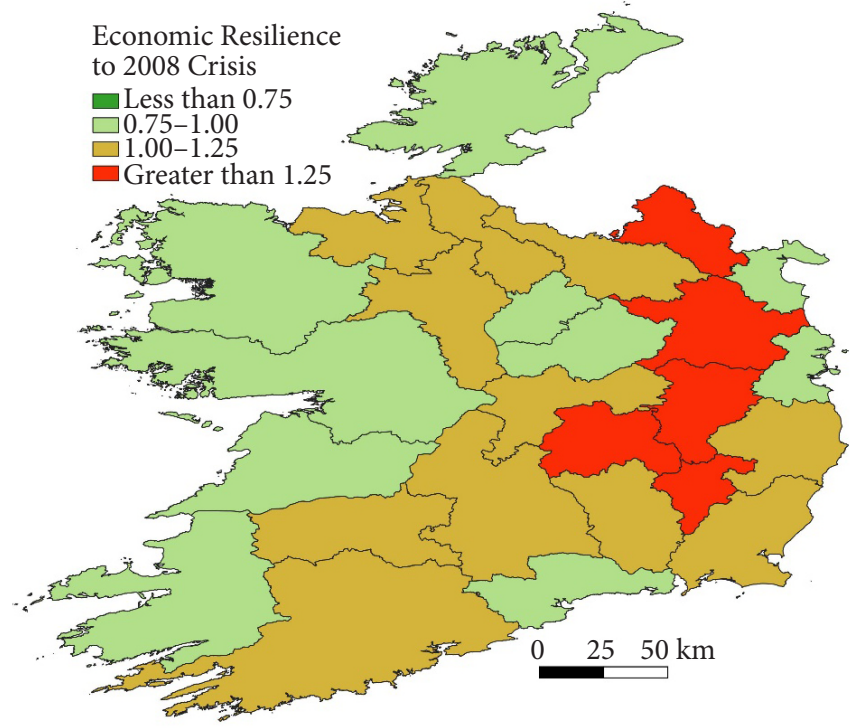

Figure 2. Economic resilience to financial crisis Source: Own calculations based on data from central statistics office

nancial crisis. This is presented in table 4 . As can be seen from the table, none of the variables were statistically significant. That is to say 'population distribution' did not have an effect on the economic resilience of counties with respect to the financial crisis.

Table 3

Impact of population distribution on economic resilience to the Covid19 crisis

\begin{tabular}{|l|c|c|}
\hline \multicolumn{1}{|c|}{ Independent Variable } & $\begin{array}{c}\text { Pearson } \\
\text { Coefficient }\end{array}$ & P-value \\
\hline Cities & 0.2327 & 0.2527 \\
\hline Satellite urban towns & $0.5911^{\star * *}$ & 0.0015 \\
\hline Independent urban towns & $-0.5328^{\star * *}$ & 0.0051 \\
\hline $\begin{array}{l}\text { Rural areas with high urban } \\
\text { influence }\end{array}$ & $0.3673^{\star}$ & 0.0649 \\
\hline $\begin{array}{l}\text { Rural areas with moderate urban } \\
\text { influence }\end{array}$ & $-0.4686^{\star *}$ & 0.0158 \\
\hline Highly rural/remote areas & -0.2762 & 0.172 \\
\hline
\end{tabular}

Source: Own calculations based on data from the central statistics office.

Table 4 nerable to unemployment caused by the Covid19 crisis. This indicates that areas with less urban influence were more resilient. One possible reason for this could be the nature of employment in the different areas. Jobs in areas classified as independent urban towns' and 'rural areas with moderate urban influence' are more likely to be considered essential i.e. employment in grocery shops and pharmacies which stayed open or employment in the agriculture sector. While jobs in 'satellite urban towns' and 'rural areas with high urban influence' may not have been considered essential.

The same analysis was carried out for the economic resilience of counties in response to the fi-
Impact of population distribution on economic resilience to the financial crisis

\begin{tabular}{|l|c|c|}
\hline \multicolumn{1}{|c|}{ Independent Variable } & $\begin{array}{c}\text { Pearson } \\
\text { Coefficient }\end{array}$ & P-value \\
\hline Cities & -0.3225 & 0.1081 \\
\hline Satellite urban towns & 0.2421 & 0.2335 \\
\hline Independent urban towns & 0.1283 & 0.5323 \\
\hline $\begin{array}{l}\text { Rural areas with high urban } \\
\text { influence }\end{array}$ & 0.2436 & 0.2304 \\
\hline $\begin{array}{l}\text { Rural areas with moderate urban } \\
\text { influence }\end{array}$ & 0.0265 & 0.8979 \\
\hline Highly rural/remote areas & -0.1325 & 0.5189 \\
\hline
\end{tabular}

Source: Own calculations based on data from the central statistics office 


\section{Conclusion}

There were two research questions at the beginning of this study. The first question we analysed was to see if economic resilience to the financial crisis was correlated to resilience to the Covid19 crisis. We can see that for counties in Ireland there was no correlation between the two. This means that counties that were resilient to the financial crisis were not necessarily resilient to the Covid19 crisis. This is important as it highlights how the two recessions are different in nature. Determinants of resilience are not concrete; they change over time and will change depending on the type of recession that occurs. Economic resilience to one recession is not a good indication of resilience to future recessions.

The second question was to do with the urban-rural divide of economic resilience. The results show that the population distribution was not a factor for the economic resilience of counties for the financial crisis. However, it was a contributing factor for economic resilience for the
Covid19 crisis. More resilient regions were the counties that had population residing in independent urban towns and rural areas with moderate urban influence. The more vulnerable regions were the counties with population concentrated in satellite urban towns and rural areas with high urban influence. This indicates that areas less reliant on urban influence were more resilient to the Covid 19 crisis and is an indication that rural areas were more resilient.

As time passes, more data will become available. Future research should focus on the economic structure of counties in Ireland and how that contributed to the economic resilience. It is likely that some sectors of the economy have been worse hit, and this will consequently affect different counties to varying degrees. For example, counties that rely on tourism and the hospitality industry are likely to be more effected by Covid19, whereas counties that rely on agriculture are likely to be more resilient. Further research into this will be fruitful.

\section{References}

Berkes, F., \& Folke, C. (1998). Linking social and ecological systems: Management practices and social mechanisms for building resilience. Cambridge University Press, Cambridge.

Breathnach, P., van Egeraat, C. \& Curran, D. (2015). Regional economic resilience in Ireland: The roles of industrial structure and foreign inward investment. Regional Studies, Regional Science, 2(1), 497-517.

Cellini, R., \& Cuccia, T. (2019). Do behaviours in cultural markets affect economic resilience? An analysis of Italian regions. European Planning Studies, 27(4), 784-801.

Central Bank of Ireland (2020). Quarterly bulletin. QB2 - April 2020 https://www.centralbank. ie/publication/quarterly-bulletins/quarterly-bulletin-q2-2020

Davoudi, S. (2012). Resilience: A bridging concept or a dead end? Planning Theory and Practice, 13(1), 299-307.

Dokic, I., Frohlich, Z. \& Bakaric, I.R. (2016). The impact of the economic crisis on regional disparities in Croatia. Cambridge Journal of Regions, Economy and Society, 9(1), 179-195. ESPON.

ESPON. (2014). ECR2 - Economic crisis: Resilience of regions. Scientific Report. Luxembourg:

Fitzgerald, J. (2014). Ireland's recovery from crisis. CESifo Forum ifo Institut - Leibniz-Institut für Wirtschaftsforschung an der Universität München, München, 15(2), 8-13.

Fröhlich, K., \& Hassink, R. (2018). Regional resilience: a stretched concept?. European Planning Studies, 26(9), 1763-1778.

Hassink, R. (2010). Regional resilience: A promising concept to explain differences in regional economic adaptability? Cambridge Journal of Regions, Economy and Society, 3, 45-58.

Hauke, J., \& Kossowski, T. (2011). Comparison of values of Pearson's and Spearman's correlation coefficient on the same sets of data. Quaestiones Geographicae, 30(2), 87-93.

Hennebry, B. (2018). Regional resilience in Ireland and the existence of a two-tier recovery. Quaestiones Geographicae, 37(4), 99-110.

Hennebry, B. (2020). The determinants of economic resilience in rural regions. An examination of the Portuguese case. Miscellanea Geographica, 24(1), 24-29. 
Holling, C.S. (1973). Resilience and stability of ecological systems. Annual Review of Ecological Systems, 4, 1-23.

Holling, C.S. (1996). Engineering resilience versus ecological resilience. In P.C. Schulze (Ed.) Engineering within ecological constraints (pp. 31-44). National Academy Press, Washington, DC.

Lang, T. (2012). How do cities and regions adapt to socio-economic crisis? Towards an institutionalist approach to urban and regional resilience. Raumforschung und Raumordnung, 70(4), 285-291.

Lapuh, L. (2018). Socio-economic characteristics of resilient localities - experiences from Slovenia. Regional Studies, Regional Science, 5(1), 149-156.

Martin, R. (2012). Regional economic resilience, hysteresis and recessionary shocks. Journal of Economic Geography, 12 (1), 1-32.

Martin, R., \& Gardiner, B. (2019). The resilience of cities to economic shocks: A tale of four recessions (and the challenge of Brexit). Papers in Regional Science, 98(4), 1801-1832.

Martin, R., \& Sunley, P. (2015). On the notion of regional economic resilience: Conceptualization and explanation. Journal of Economic Geography, vol. 15(1), 1-42.

Morgenroth, E. (2014). Two-speed recovery? Spatial development in Ireland. ESRI Research Notes $4 / 2$.

Ringwood, L., Watson, P. \& Lewin, P. (2018). A quantitative method for measuring regional economic resilience to the great recession. Growth and change 2018, 1-22.

Rodgers, J.L., \& Nicewander, W.A. (1988). Thirteen ways to look at the correlation coefficient. The American Statistician, 42(1), 59-66

Ruane, F. (2016). Ireland - a remarkable economic recovery? The Australian Economic Review, 49(3), 241-250.

Sánchez-Zamora, P., Gallarado-Cobos, R. \& Cena-Delgado, F. (2014). Rural areas face the economic crisis: analyzing the determinants of successful territorial dynamics. Journal of Rural Studies, vol. 35(2014), 11-25

Sensier, M., \& Artis, M. (2016). The resilience of employment in Wales: through recession and into recovery. Regional Studies, 50(4), 586-599

Simmie, J.M., (2017). The Evolution of Economic Resilience in Cities: Re-invention versus replication. In N. Williams \& T. Vorley (Ed.) Creating Resilient Economies: Entrepreneurship, Growth and Development in Uncertain Times (pp. 70-88). Cheltenham, Edward Elgar.

Simmie, J., \& Martin, R. (2010). The economic resilience of regions: Towards an evolutionary approach. Cambridge Journal of Regions, Economy and Society, 3(1), 27-43.

Tan, J., Lo, K., Qiu, F., Liu, W., Li, J. \& Zhang, P. (2017). Regional economic resilience: Resistance and recoverability of resource-based cities during economic crises in northeast China. Sustainability, 9(12), 2136.

Tóth, B.I. (2015). Regional economic resilience: concepts, empirics and a critical review. Miscellanea Geographica, 19(3), 70-75.

\section{Information about the author}

Barraí Hennebry - Assistant Lecturer, Department of Accounting and Business Computing, Athlone Institute of Technology (Dublin Road, Athlone, Co Westmeath, Ireland); ORCID: https:// orcid.org/0000-0001-7150-7691; e-mail: bhennebry@ait.ie

ARTICLE INFO: received July 31, 2020; accepted September 14, 2020

\section{Информация об авторе}

Хеннебри Бэррэй - преподаватель кафедры бухгалтерского учета и бизнес-вычислений, Атлонский технологический институт (Дублин-роуд, Атлон, графство Уэстмит, Ирландия); ORCID: https://orcid.org/0000-0001-7150-7691; e-mail: bhennebry@ait.ie

ИНФОРМАЦИЯ О СТАТЬЕ: дата поступления 31 июля 2020 г.; дата принятия к печати 14 сентября 2020 г. 


\section{Appendix}

Population distribution for Ireland and each county

\begin{tabular}{|c|c|c|c|c|c|c|}
\hline & Cities, \% & $\begin{array}{c}\text { Satellite } \\
\text { urban } \\
\text { towns, \% }\end{array}$ & $\begin{array}{c}\text { Independent } \\
\text { urban towns, \% }\end{array}$ & $\begin{array}{c}\text { Rural areas } \\
\text { with high urban } \\
\text { influence, } \%\end{array}$ & $\begin{array}{c}\text { Rural areas with } \\
\text { moderate urban } \\
\text { influence, } \%\end{array}$ & $\begin{array}{c}\text { Highly } \\
\text { rural/remote } \\
\text { areas, \% }\end{array}$ \\
\hline State & 33 & 13 & 16 & 16 & 13 & 9 \\
\hline Carlow & 0 & 0 & 49 & 19 & 26 & 5 \\
\hline Cavan & 0 & 0 & 31 & 9 & 27 & 33 \\
\hline Clare & 4 & 2 & 33 & 25 & 16 & 20 \\
\hline Cork & 38 & 19 & 6 & 24 & 8 & 5 \\
\hline Donegal & 0 & 0 & 28 & 9 & 22 & 41 \\
\hline Dublin & 87 & 11 & 0 & 2 & 0 & 0 \\
\hline Galway & 29 & 11 & 4 & 34 & 12 & 10 \\
\hline Kerry & 0 & 0 & 34 & 11 & 27 & 27 \\
\hline Kildare & 0 & 56 & 12 & 28 & 4 & 0 \\
\hline Kilkenny & 5 & 0 & 33 & 29 & 26 & 7 \\
\hline Laois & 0 & 0 & 48 & 24 & 21 & 7 \\
\hline Leitrim & 0 & 0 & 10 & 1 & 20 & 69 \\
\hline Limerick & 45 & 3 & 5 & 29 & 13 & 4 \\
\hline Longford & 0 & 0 & 34 & 4 & 38 & 24 \\
\hline Louth & 0 & 0 & 67 & 20 & 11 & 2 \\
\hline Mayo & 0 & 0 & 29 & 7 & 26 & 37 \\
\hline Meath & 0 & 49 & 10 & 32 & 7 & 2 \\
\hline Monaghan & 0 & 0 & 30 & 7 & 43 & 21 \\
\hline Offaly & 0 & 0 & 43 & 24 & 25 & 8 \\
\hline Roscommon & 0 & 0 & 27 & 15 & 31 & 27 \\
\hline Sligo & 0 & 0 & 39 & 11 & 29 & 21 \\
\hline Tipperary & 0 & 3 & 39 & 19 & 30 & 9 \\
\hline Waterford & 41 & 12 & 8 & 16 & 18 & 5 \\
\hline Westmeath & 0 & 3 & 46 & 25 & 21 & 5 \\
\hline Wexford & 0 & 0 & 39 & 17 & 31 & 13 \\
\hline Wicklow & 0 & 55 & 10 & 26 & 7 & 2 \\
\hline
\end{tabular}

Source: Own calculations using data from central statistics office 